Brit. J. vener. Dis. (1966), 42, 42.

\title{
PERFORMANCE AND USE OF THE REITER PROTEIN COMPLEMENT-FIXATION (RPCF) TEST*
}

\author{
BY \\ J. H. BEKKER, J. H. DE BRUIJN, AND J. N. MILLER \\ From the Laboratory of Bacteriology and Serology, National Institute of Public Health, Utrecht, Netherlands
}

The immunological basis for the use of the RPCF test in the sero-diagnosis of syphilis is the fact that Treponema pallidum and Treponema reiteri share a genus-specific protein antigen. Although the Reiter protein antigen appears to be a lipo-polysaccharideprotein complex (de Bruijn, 1959), it has been assumed that only the protein component is responsible for the reactivity with syphilitic serum.

In previous papers we have recommended the application of the RPCF test as a simple, sensitive, and specific test. As is the case with all serological procedures, the sensitivity and specificity of the RPCF test are dependent upon a number of factors, not the least important being the technique by which it is performed. In our experience with many thousands of sera, optimal sensitivity can be obtained utilizing the complement-fixation technique of either de Bruijn (1958) or Kolmer (1942), in which 1.5 exact units of complement are employed (Bekker, $1959,1960)$. Further testing of undiluted serum in a final concentration of $1: 6$, as performed in our laboratory, is deemed essential. The use of serum in a final dilution of $1: 17 \cdot 5$ as described in the "Manual of Serologic Tests for Syphilis" (U.S. Dept. of Health, 1964) considerably reduces the number of reactive results. This can be demonstrated from our findings on 1,260 syphilitic sera, in which 173 (13.7 per cent.) showed a reactive RPCF test only with undiluted serum (final dilution 1:6) and 344 (19.7 per cent.) exhibited a serum titre of $1: 2$ (final dilution 1:12). It can be readily seen that syphilis would not have been detected in 33.4 per cent. of the sera tested had procedures been employed in which the initial final dilution was greater than $1: 12$. The observation by one of us that a non-reactive test on undiluted syphilitic sera may be due to a prezone or related phenomenon (Bekker, 1962) stresses the importance of testing each serum

* Received for publication June 29, 1965 quantitatively. The RPCF test carried out as described under controlled standardized conditions has an excellent reproducibility (Bekker, 1962). In our experiments, repeat testing of the same sera on consecutive days never gave differences in titre of more than one dilution.

We have emphasized the use of the RPCF test in conjunction with and for confirmation of the cardiolipin tests and as a preselection procedure for the TPI test (Bekker, 1960; Carpenter, Miller and Boak, 1960; de Bruijn, 1962). Contrary to other investigators, we are of the opinion that the RPCF test can neither replace the cardiolipin tests nor be employed as a screening procedure in mass investigations. We base this opinion on the fact that apparently nonspecific reactive RPCF tests are found in sera which are non-reactive to the TPI test and come from persons without present or past treponemal infection (Bekker, 1962). This limitation in specificity is not surprising inasmuch as no laboratory test for syphilis is perfect and reactive results in non-syphilitic sera occur with all tests. In our attempts to determine the origin of this non-specificity, the possibility that it could be caused by an antibody against another component of the complex, viz. the lipopolysaccharide, was explored. A total of 6,000 sera from healthy blood-donors with non-reactive cardiolipin results were tested with RPCF antigen which had been heated for $30 \mathrm{~min}$. at $100^{\circ} \mathrm{C}$. to inactivate the protein without damaging the type-specific lipopolysaccharide portion of the molecule (de Bruijn, 1959). Reactivity was obtained in $58(0.96$ per cent.) of the 6,000 sera tested. Thus, the presence of an antibody against the lipopolysaccharide moiety was indicative of a non-specificity in just under 1 per cent. of normal individuals. Similar findings were reported by Pillot and Dupouey (1964). From an earlier investigation, it appeared that this antibody occurs in syphilitic more frequently than in non-syphilitic sera (de Bruijn, 1961, 1963). Further study indicated 
its presence in $52(10.9$ per cent.) of 477 syphilitic sera reactive to the STS, RPCF, and TPI tests. This low incidence, although ten times higher than in "normal" sera, makes it unlikely that the antibody is provoked by $T$. pallidum. Despite the fact that a heterogenetic origin cannot be excluded, it seems reasonable to assume that $T$. reiteri, acting as a saprophytic contaminant of the syphilitic lesion, may be the causative agent. Since Zaffiro (1962) showed the survival of $T$. reiteri in rabbit testicles inoculated with the Nichols strain of $T$. pallidum, we investigated the antibody response under these circumstances. Each of the rabbits inoculated with both strains as well as the control animals inoculated with the Nichols strain only developed the same antibody titres against $T$. reiteri lipopolysaccharide. This observation points to a common lipopolysaccharide antigen(s) in the rabbit-adapted Nichols strain of $T$. pallidum and in $T$. reiteri, and to previously unsuspected antigenic differences between animal adapted and so-called "wild" strains of $T$. pallidum (Bekker and de Bruijn, 1964; Miller, de Bruijn, and Bekker, to be published).

The question which arises then is whether these findings impair the value of the RPCF test in the sero-diagnosis of syphilis. As previously indicated, we found an incidence of non-specific reactive RPCF tests in approximately 1 per cent. of sera from healthy donors with non-reactive cardiolipin tests. This incidence exceeds that of non-specific reactive cardiolipin tests; of 10,000 unselected sera, we found 125 reactive in the STS, ten $(0 \cdot 1$ per cent.) of which appeared to be non-specific (Bekker, 1960). These data clearly show the danger of the indiscriminate use of the RPCF test. If we compare the cause of the non-specificity of both the cardiolipin and RPCF tests, we may assume that there is probably no correlation between the occurrence of the respective antibodies. If this is true, then the probability of a combination of both non-specificities is the arithmetic product of each, in our investigation 0.001 per cent. Consequently, the proper use of the RPCF test is its application in conjunction with and for corroboration of the cardiolipin tests with which the serological investigation must be started. Only in this way does the risk of non-specific results become minimal.

\section{Summary}

To gain maximum benefit from the use of the RPCF test the following considerations must be taken into account:

(1) The test must be performed with one of the described complement-fixation techniques under standardized conditions.

(2) The test must be carried out with undiluted serum in a final concentration of $1: 6$.

(3) The test must be used and the results interpreted in conjunction with and for corroboration of the cardiolipin tests.

\section{REFERENCES}

Bekker, J. H. (1959). Brit. J. vener. Dis., 35, 129. (1960). Ned. T. Geneesk., 104, 1935. (1962). Brit. J. vener. Dis., 38, 131. and de Bruijn, J. H. (1964). Abstr. in "Proc. XIV Symposium on Recent Advances in the Study of Venereal Diseases, Houston, Texas, 1964", p. 9. U.S. Dept. of Health, Education, and Welfare.

Bruijn, J. H. de (1958). Antonie v. Leeuwenhoek, $24,69$. (1959). Ibid., 25, 41.

(1961). Thesis, Utrecht

(1962). Brit. J. vener. Dis., 38, 126.

(1963). J. gen. Microbiol., 31, iii.

Carpenter, C. M., Miller, J. N., and Boak, R. A. (1960). New Engl. J. Med., 263, 1016.

Kolmer, J. A. (1942). Amer. J. clin. Path. 12, 109.

Miller, J. N., de Bruijn, J. H., and Bekker, J. H. To be published.

Pillot, J., and Dupouey, P. (1964). Ann. Inst. Pasteur, $106,456$.

U.S. Dept. of Health, Education, and Welfare (1964). "Serologic Tests for Syphilis, 1964 Manual". U.S. Public Health Service Publication No. 411 (rev. May, 1964). Government Printing Office, Washington, D.C.

Zaffiro, P. (1962). Riv. Ist. sieroter. ital., 37, 614.

Le fonctionnement et l'usage du test de fixation du complément de la protéine de Reiter (FCPR)

RÉSUMÉ

Afin de tirer tout le profit en se servant du test FCPR, les considérations suivantes doivent être tenues en compte:

(1) Le test doit être fait selon une des techniques décrites de la fixation du complément sous des conditions standardisées.

(2) Le test doit être fait avec du sérum non-dilué dans une concentration finale de $1: 6$.

(3) Le test doit être fait en conjonction avec les tests de cardiolipine et les résultats obtenus corroborés avec eux. 